\title{
A Needs Analysis of the Written Communication - What Say the Lawyers?
}

\section{Manvender Kaur Sarjit Singh}

\author{
School of Education and Modern Languages, College of Arts and Sciences, Universiti Utara Malaysia \\ Sintok, Kedah, Malaysia; Email: manvender@uum.edu.my
}

Doi:10.5901/mjss.2015.v6n6s2p230

\begin{abstract}
A rule of the thumb is: you apply what you have learnt. However, many have failed to do so. This paper reports the lack of ability to apply the learnt knowledge into real-life context of the legislative communicative event of writing the important legal documents. Parameters of Munby's Communication Needs Processor (CNP) were adapted and used to investigate the need to master the written communication in the legislative domain. The data was gathered from semi-structured interviews with selected specialist informants who are legal practitioners in legal firms. Thematic analysis was applied to the responses received. The findings highlighted crucial problems faced by legal practitioners when employing fresh graduates from law faculties of various higher learning institutions in the nation. The findings are deemed important and are used to justify the need of a research investigating the written legislative discourse.
\end{abstract}

Keywords: Needs Analysis, Communicative Needs Processor, Target Needs Analysis, Situational Needs Analysis, English for Specific Purposes (ESP).

\section{Introduction}

A rule of thumb is: you apply what you have learned. In language classrooms, this notion has been treated with foremost priority, concerning the language needs of many prospective employers of the learners. The increasing demand of English language especially in terms of employments has generated a new perspective of teaching the language. Various language needs analysis has been conducted locally and globally (Nur Muhammad Insan Jalil, 2005; Manvender, 2004; Eslami, 2010; Viator, 2012), in order to highlight the fundamental requirement of the language, in terms of job accomplishment.

A Needs Analysis in the context of language use is an activity carried out to identify learners' specific language needs and requirements (Fatihi, 2003; Songhori, 2008). In order to develop suitable course content of a particular ESP course design, conducting a Needs Analysis becomes a crucial point of progression into syllabus and materials development.

Needs analysis enables course designers to define learners' learning objectives more clearly. A target situation analysis is an approach of needs analysis which is conducted to identify and establish learners' language requirements. For this particular study, the target situation needs analysis was conducted using Munby's (1978) Communicative Needs Processor (CNP) Model and was aimed at identifying and establishing the workplace English language needs of legislative practitioners.

Placed within the qualitative method of inquiry, the study used semi-structured interview questions in order to gain reliable and comparable qualitative data from the respondents of the study. Semi-structured interviews can be useful and well suited to assist in the exploration of attitudes, values, beliefs and motives of the respondents (Smith, 1975).

\section{Literature Review}

Globally, language teaching is contained within a number of specific methods and approaches. The concept of methods and approaches in language teaching refers to systematical traditions developed and used to teach languages, relying heavily on theories of language teaching and language learning (Richards \& Rodgers, 2001:1). Besides ESP, the teaching of English for Academic (EAP) has also been criticized for not having sufficient findings related to the needs and requirement of students and instructors of the EAP courses (Eslami, 2010). Locally, there have been some concerns over the teaching of English language in Malaysia (Ismail, 2009; Gurvinder and Sharan, 2008; Manvender, 2004).

Malaysian graduates are found to be lacking abilities in applying the learnt English language knowledge into their real world language demands. Gurvinder and Sharan (2008) highlighted the lack of seven soft skills among graduates in 
Malaysia. The seven soft skills are; problem solving and adaptability, interpersonal and ability to work as a team, English language proficiency, information communication and technology, personal organization and time management, leadership and communication (Gurvinder and Sharan, 2008). English language proficiency seems to be an important skill required for employment. Having paper qualification no longer guarantees employment (Gurvinder and Sharan, 2008).

Unemployment rate among graduates in Malaysia is still at a critical level (Lai, 2011). According to the 2010 Graduate Tracer Study conducted by Ministry of Higher Education (MoHE) in Malaysia 42, 955 or $24.6 \%$ of graduates are unemployed, while 12,250 or $7.0 \%$ are waiting for work placement. Among the listed figures, the statistics also showed that 2,477 or $1.4 \%$ of the graduates are developing skills required for employment.

In Malaysia, English is taught and used as a second language and is a fundamental requirement for career advancement. As mastering English requires mastering the spoken and written aspects of the language, English for Specific Purposes (ESP) courses have been integrated into various curricula in the country. Since the 1990s, there has been increased emphasis of learning English especially due to the demands of globalization and internationalization (Khairi Izwan Abdullah, 2001). Now, English language is taught not only to meet academic needs of students in higher learning institutions but also to meet specific occupational needs which include legislative practices among lawyers (Khairi Izwan Abdullah, 2001).

According to Nur Muhammad Insan Jalil (2005), without conducting a needs analysis, there is a danger of preparing a course which is not fully catered to students' specific occupational needs, especially when students come from various different disciplines of studies. Legislations, among other occupations, involve both the private and also the government sector. Manvender (2004) conducted a needs analysis in the government sector involving Customs front line officers from the Royal Customs Department of Malaysia and found that English skills are indeed important and are lacking among the front liners.

In order to explore the effectiveness of ESP teaching practices in Malaysia, especially the teaching of ESP writing, it is necessary to first examine how written English is used in the prospective workplaces of students, such as in the law firms. Written workplace literacy in law firms in Malaysia has yet to be explored and requires investigation. Thus, before further curricular suggestions can be made, research exploring the actual written communication of Malaysian law firms is first necessary in order to understand what language learners will need in real work situations after completing their studies. Once a picture of the English language needs has been formed, this can inform pedagogy and syllabus planning.

\section{Research Objective}

The main objectives of the study conducted were:

a) To identify the written legal documents prepared by the legal practitioners in Malaysia and;

b) The extent of workplace English language needs and requirements of prospective future

legislative practitioners such as legal officers, legal assistants and lawyers.

\section{Research Question}

Following the research objectives, this study was conducted to answer the following research questions;

a) What are the written legal documents prepared by legal practitioners in Malaysia?

b) To what extent is English language required and used by the practicing legal practitioners?

\section{Methodology}

The research approach employed in this study is a qualitative approach, using the research method of semi-structured interviews to answer the research questions.

A set of semi-structured interview questions was designed based on Munby's (1978) Communicative Needs Processor (CNP) Model. Munby's (1978) CNP Model was found to be useful for this study as it collects information related to the use of language by the learners in their prospective workplaces. However, some parameters from the CNP Model was adapted and suited within the need of the present inquiry.

Using thematic analysis, the responses from the semi-structured interviews were then used to identify suitable themes in order to provide answers to the research questions.

Respondents for the semi-structured interviews were selected from three law firms in the country, each from Alor Setar, Kedah; Petaling Jaya, Kuala Lumpur and Johor Bahru, Johor. The profiles of the respondents for the interviews 
are presented in Table 1.

Table 1: Profiles of the respondents for the interviews

\begin{tabular}{|c|c|c|c|}
\hline LAW FIRM & CODING & AGE $^{*}$ & EXPERIENCE $^{*}$ \\
\hline A & LPA-01 & 53 & 23 \\
\hline B & LPB-01 & 58 & 30 \\
\hline C & LPC-01 & 47 & 18 \\
\hline
\end{tabular}

${ }^{*}$ Age and experience are given in years. Experience refers to the respondents experience working as legal practitioners.

In order to sustain ethical considerations and confidentiality issues, the interview sessions were held at the convenience of the respondents and at various different locations, out of their formal workplace. Each interview session lasted between one to two hours. Recording was avoided as the respondents were against it and preferred to be informally interviewed. Thus, the responses were taken down as notes.

Although not limited to, the interview questions were placed within the adapted parameters of the CNP Model. The constructs of the semi-structured interview questions asked are as shown in Table 2 below.

Table 2: Construct of the Interview Questions

\section{Parameters of CNP}

1. Participants - the Purposive Domain

2. Communication Needs Processor - the Interaction Domain

\section{Interview Question}

1. What are the legal documents prepared by legal practitioners in your firm?

2. Do you employ fresh law graduates?

3. Are the newly employed legal practitioners (fresh law graduates) in your firm use English language?

\section{Is English language important in your firm?}

5. To what extent is English language used in your firm?

6. Are the written legal documents in your firm prepared using English language?

7. To what extent it is important to prepare the written legal documents in English language?

The interview questions were asked according to two main domains of the CNP Model; the Purposive Domain and the Interaction Domain. Questions within the Purposive Domain include questions that require the respondents to provide information regarding the purpose of preparing the legal documents in English language and the purpose of English language use in the firms. Subsequently, the Interaction Domain was adapted in order to generate responses related to the importance of workplace English language use and the importance of preparing the written legal documents in English language.

\section{Data Analysis}

Responses from the semi-structured interviews were analysed using thematic analysis. The themes emerged from the thematic analysis were tabulated as shown in Table 3.

During the thematic analysis, the responses were identified according to related responsive themes that emerged from the qualitative analysis of the data, for example; question 1 asked about the types of legal documents that are prepared by the legal practitioners. Thus, the responding theme was labeled as Types of legal documents prepared by the legal practitioners.

Four major themes emerged from the analysis; types of legal documents prepared by the legal practitioners, level of English language use by fresh law graduates, importance of English language use in the legal firms and importance of preparing the legal documents in English language.

These themes were then used to provide answers to the two research questions of this study. The discussion of the emerging themes is supported by some examples of the responses received during the semi-structured interview sessions. 
Table 3: Findings from the thematic analysis

\begin{tabular}{|l|l|}
\hline Interview Questions & Themes \\
\hline 1. What are the legal documents prepared by legal practitioners in your firm? & $\begin{array}{l}\text { Types of legal documents prepared by the } \\
\text { legal practitioners }\end{array}$ \\
\hline 2. Do you employ fresh law graduates? & $\begin{array}{l}\text { Level of English language proficiency among } \\
\text { fresh law graduates }\end{array}$ \\
\hline $\begin{array}{l}\text { 3. Are the newly employed legal practitioners (fresh law graduates) in your firm use English } \\
\text { language? }\end{array}$ & $\begin{array}{l}\text { Importance of English language use in the } \\
\text { legal firms }\end{array}$ \\
\hline 4. Is English language important in your firm? & $\begin{array}{l}\text { Importance of preparing the legal documents } \\
\text { 5. To what extent is English language used in your firm? }\end{array}$ \\
\hline 6. Are the written legal documents in your firm prepared using English language? &
\end{tabular}

\section{Findings and Discussion}

The discussion is provided according to the four themes that emerged from the thematic analysis of the responses received.

\subsection{Types of Written Legal Documents}

The findings from the interviews highlighted various types of written legal documents that are prepared by the legal practitioners. It was crucial to identify the types of written legal documents prepared by present legal practitioners in Malaysia as this information provided answers to research question (a) What are the written legal documents prepared by legal practitioners in Malaysia?

The types of written documents prepared by the legal practitioners in Malaysia are summarized and presented in Table 4 below.

Table 4: Types of legal documents prepared by the legal practitioners

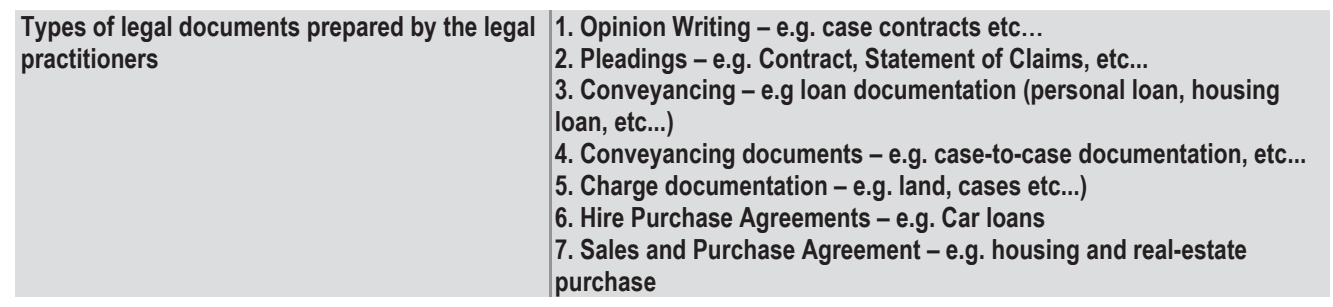

According to the interview question "What are the legal documents prepared by legal practitioners in your firm?" almost all the respondents provided similar responses. For example, respondent coded as LPA-01 stated that;

"basically...we write many types of legal documents...including contracts, claim statements and loan documents"

Further probing was required in order to gain the needed information from the respondent. The researcher listed out the documents in a piece of paper and probed the respondent into confirming the types of documents prepared. Further clarifications were made by asking similar question to other respondents.

All respondents claimed that the major written legal documents are within the general categories of "...opinion writing, pleadings, conveyancing, charge documentations, hire purchase agreements and sales and purchase agreements". These documents, according to all of the respondents, are prepared on 'case-by-case' basis. The term 'case-by-case' was further clarified by probing and asking "What do you mean by 'case-by-case'? to which the respondents stated that the documents are prepared according to individual needs and purposes. The documents are prepared for one case at a time. According to respondent coded as LPB-01, "we prepare the document for specific clients only...it is the nature of our business...each document is for one case...that's what I mean by case-by-case"

Another interesting statement made by respondent coded as LPC-01 is that "...every single case is unique, especially murder cases...so we have to look at it on case-to-case basis". 
It was noticed that the sales and purchase agreements were almost similar to one another. The researcher further probed and confirmed the fact that this document follows a particular standardized format, which according to one respondent, (coded as LPB-01) "...has been around for more than a century!"

According to respondent coded as LPC-01; "the sales and purchase agreement has the same outline...there's nothing much to alter...we will normally have a standard format ready in the computer and...we will just add necessary information of the clients in it...and it's ready"

\subsection{Level of English language proficiency among fresh law graduates}

During the interview sessions, it was stated by the respondents that fresh law graduates employed by the firms have difficulties using English language, whether it is in the form of written or spoken.

Respondent coded as LPA-01 stated that "normally the newly employed legal assistants...those who just completed their studies... have problems... they can't even write what we told them to write".

According to respondent coded as LPC-01, "we have to really guide them from the basic...they supposed to make our job easier but...it's not happening"

Further probing indicated that English language use among fresh law graduates, who were newly employed by these firms seems to be a problematic area. It was also indicated that the use of English language is crucial. However, the fresh law graduates seem to be incapable of using the language sufficiently. Respondent coded as LPA-01 stated that;

"I'm sure these interns are supposed to be able to use the language...but we are always having problems to correct them...especially when it comes to writing....we have to show them examples... and they will just copy paste"

\subsection{Importance of English language use in the legal firms}

The findings of the semi-structured interviews also indicated the importance of English language use in the law firms.

All the respondents agreed that English language is the most important language used by lawyers. However, the lawyers are also required to be able to use Bahasa Malaysia proficiently. It was indicated that in Malaysian courts, it was necessary to use Bahasa Malaysia during the sessions. However, according to the respondents, the use of English language is important as Malaysian laws are bound by British legislative system and all the reference books are in English language.

Respondent coded as LPC-01 stated that "the legislative books are mainly from U.K. and India....so how can these fresh grads not use the language...it's the language of law".

Another respondent (coded as LPA-01) mentioned that "as Malaysian law follows the British legislative system...the lawyers here have to be very good in interpreting the law books'.

\subsection{Importance of preparing the legal documents in English language}

The respondents indicated that it is crucial and fundamental for most of the legal documents to be prepared in English language as it generally reflects the legislative system being employed at present, in the country.

According to respondent coded as LPB-01, the "basic concept of preparing the legal documents is to fulfill the legislative requirement which, according to the respondent, is grounded in the origin of Malaysian's legislative system".

It was also indicated that the legal documents are considered to be very important documents and mistakes are intolerable as mistakes will lead to ambiguities in language use.

\section{Conclusion}

Conducting a Needs Analysis was found to be suitable in order to find answers to the two research questions. The first research question was answered using the feedback received from the legal practitioners, in terms of the types of legal documents being prepared by the present legal practitioners. Subsequently, the thematic analysis conducted on the response from the semi-structured interview questions indicated that English language is important in the legal firms and that the fresh law graduates are required to master the language in order to be competent legal practitioners.

Most importantly, the findings supported claims made by many including by Nur Muhammad Insan Jali \& Mohd Fauzi Kamarudin (2009), Manvender (2004), Eslami (2010) and Viator (2012) that there is a crucial need to look into the 
legislative domain in order to highlight language needs of the learners.

The findings identified seven types of written legal documents. As English language plays a crucial role in the employment of legal practitioners, the findings also indicate a necessity to investigate how these legal documents are prepared in order to assist present undergraduates of law courses offered in various higher learning institutions in Malaysia.

Generally, the need to examine and to highlight the strategies used while preparing the legal documents was also indicated by the respondents. The fundamental requirement of research into written legislative discourse was justified by the answers provided for the two research questions of the present study. Thus, the findings of the present study will be used to proceed into an investigation of the written legislative discourse where selected samples of the written legal documents will be gathered and analysed further.

\section{Acknowledgments}

This work is funded by the Malaysian Government under the FRGS Grant No.: 66443-77380 with the Reference No.: FRGS/2/2014/SSI01/UUM/03/1.

\section{References}

Eslami, Z.R. (2010). Teachers' Voice vs. Students' Voice: A Needs Analysis Approach to English for Academic Purposes (EAP) in Iran. English Language Teaching. Vol. 3, No.1.

Fatihi, R.A. (2003). The Role of Needs Analysis in ESL Program Design. In South Asian Language Review. Vol. XIII, No. 1 \& 2. JanuaryJune.

Gurvinder Kaur Gurcharan Singh and Sharan Kaur Garib Singh. (2008). Malaysian Graduates Employability Skills. UNITAR E-Journal, vol. 4, no.1, Jan. 2008.

Ismail, I. (2009). English in the Teaching of Mathematics and Science Subjects (ETeMS) Policy: Implications for the performance of Malaysian secondary schools in Mathematics and Science subjects. Soreze, France.

Khairi Izwan Abdullah. (2001). English for Specific Purposes in Malaysia: International Influence, Local Flavour.Journal of Southeast Asia Education, Vol. 2, No.2, pp. 345-361

Manvender, K. (2004). A Training Needs Analysis for Front-Line Customs Officers - A Case Study at Kompleks Sultan Abu Bakar, Tg, Kupang. Unpublished Masters Thesis. Universiti Teknologi Malaysia.

Munby, J. (1978). Communicative syllabus design. London: Cambridge University Press.

Nur Muhammad Insan Jalil (2005). EAP Needs Analysis for Undergraduates at IIUM's

Ahmad Ibrahim Kulliyah of Law. Unpublished Master's Thesis. International Islamic University, Malaysia.

Richards, Jack C. and Rodgers, Theodore S. (2001). Approaches and Methods in Language Teaching. (2nd edition). Cambridge: Cambridge University Press

Smith, H. W. (1975). Strategies of social research methodological imagination. Prentice Hall International, London.

Songhori, M.H. (2008). Introduction to Needs Analysis. English for Specific Purpose world, Issue 4, www.esp-world.info

Viator, J.E. (2012). Legal Education's Perfect Storm: Law Students' Poor Writing and Legal Analysis Skills Collide with Dismal Employment Prospects, Creating the Urgent Need to Reconfigure the First-Year Curriculum. Catholic University Law Review. Vol. 61. Issue 3. 